\title{
Geopolitics
}

\section{The Metamorphosis of Metaphors of Vision: "Bridging" Turkey's Location, Role and Identity After the End of the Cold War}

\section{Lerna K. Yanık}

To cite this article: Lerna K. Yanık (2009) The Metamorphosis of Metaphors of Vision: "Bridging" Turkey's Location, Role and Identity After the End of the Cold War, Geopolitics, 14:3, 531-549, DOI: $10.1080 / 14650040802693515$

To link to this article: https://doi.org/10.1080/14650040802693515

曲 Published online: 18 Aug 2009.

Submit your article to this journal $\pi$

Џ Article views: 479

4 Citing articles: 24 View citing articles 


\title{
The Metamorphosis of Metaphors of Vision: "Bridging" Turkey's Location, Role and Identity After the End of the Cold War
}

\author{
LERNA K. YANIK \\ Department of Political Science, Bilkent University, Ankara, Turkey
}

\begin{abstract}
During the Cold War, "buffer" or "bastion" seemed a popular metaphor to describe Turkey. After the Cold War, "bridge," (and, to some extent, the "crossroad") metaphor started to dominate the Turkish foreign policy discourse. This article traces the use of "bridge" metaphor in this discourse in the post-Cold War period by the Turkish foreign policy elite. It develops two arguments. First, the word bridge is a "metaphor of vision" combining Turkey's perceived geographical exceptionalism with an identity and a role at the international level. As a "metaphor of vision," the employment of the word "bridge" highlighted Turkey's liminality and justified some of its foreign policy actions to Eurasia and then to the Middle East. Second, because the bridge metaphor was used in different context to justify different foreign policy choices, its meaning has changed, illustrating that metaphors are not static constructs. It concludes by saying that the continuous use of "bridge" metaphor might reinforce Turkey's "liminality, " placing Turkey in a less classifiable category than the regular "othering" practices.
\end{abstract}

When the subject is Turkish politics, one frequently encounters books or articles that contain the words "Turkey," "between," "East" and "West" in their titles. ${ }^{1}$ Even if the title does not contain any of these words, it is very likely that, be it an article, a book or a monograph, there will be a reference to how "important," "troubled," or for that matter, "difficult," Turkey's geography is. ${ }^{2}$ Such titles are so abundant that sometimes rather than saying something new about Turkey's politics, they end up bolstering Turkish geographical "exceptionalism." Oftentimes, this reference to Turkey's

Address correspondence to Lerna K. Yanık, Department of Political Science, Bilkent University, Bilkent 06800, Ankara, Turkey. E-mail: yanikl@bilkent.edu.tr 
geographical "exceptionalism" is created, recreated and highlighted when policy makers, media and academia employ metaphors to describe Turkey's "uniqueness." 3

During the Cold War, "buffer" or "bastion" seemed a popular metaphor to describe Turkey. After the Cold War, the "bridge," (and, to some extent, the "crossroad") metaphor has come to dominate the discourse, not only discursively, but also visually. In addition to various policy makers referring to Turkey as a "bridge," the image of Ortaköy Mosque in the foreground and Bosphorus Bridge in the background, as seen from Istanbul's wellknown Ortaköy Square, for example, has become a stereotypical photo backdrop for officials ranging from George W. Bush, in June 2004 to Queen Elizabeth II, in May 2008, and many others before and after them, (re)producing Turkey's "exceptionalism." This article examines the discursive creation of this geographical exceptionalism through the use of the "bridge" metaphor, by Turkish officials in the context of Turkish foreign policy discourse in the post-Cold War period.

Needless to say, Turkey is neither the only country to associate itself with a metaphor nor to make a claim to geographical "exceptionalism" by using metaphors in its foreign policy discourse. One can easily find numerous cases, where different countries (or regions, for that matter) are associated with metaphors such as a bridge, crossroads, fortress, etc. ${ }^{4}$ In other words, the claim for exceptionalism is no exception, and since many different countries make the claim to be "exceptional" in some geopolitical sense, in the end, no country is that exceptional.

Yet there are several reasons that make the study of Turkish "exceptionalism" worthwhile. First, the metaphors underscoring Turkey's "uniqueness" are more than a geopolitical imagination/representation, or a "branding strategy," as has been argued elsewhere. ${ }^{5}$ Borrowing the term "geopolitical visions" from Dijkink, ${ }^{6}$ I refer to these metaphors as "metaphors of visions." Geopolitical visions are the ways in which a state relates itself to the world order. This relating process, Dijkink argues, comes as a result of how a state's elites perceive their history, think of their national identity, and imagine their country's location, eventually, all affecting how these elites plan and execute a country's foreign policy. ${ }^{7}$ Put differently, these metaphors do not merely imply imaginations or representations regarding the geographical location of a country. In addition to geographical imaginations/representations, they also give us clues to the international role and the identity that a state aspires to, or plans to become. Second, the Turkish case is a paradoxical one. When Turkish officials willingly use the metaphor "bridge" or claim that Turkey is located at the "crossroads," or the "intersection" of three continents, it means that Turkish officials are consciously settling with a liminal, and, recently, with a liminalmarginal international identity. As has been argued by most scholars of international relations, liminality is neither a wise thing to be nor to 
become. ${ }^{8}$ As a result of the Turkish officials' willingness to use the "bridge" metaphor to highlight Turkey's liminality, Turkey's "othering" by Europe (and now by the European Union [EU]), which has persisted since medieval times, is continuously reinforced, this time in a liminal manner, not by the Europeans or the EU per se, but by the Turkish elite. Third, despite the existence of literature that depicts Turkey's international affairs in metaphorical terms, ${ }^{10}$ so far there has not been an attempt to analyse these metaphors of vision that Turkish elites use. Consequently, I believe, not the Turkish geography, but the study of Turkey's geographical "exceptionalism" is exceptional.

I develop two arguments while tracing and analysing metaphors of vision that Turkish foreign policy elites use. As noted previously, these metaphors, on the surface denote only geography, but in reality, combine geographical imaginations, role and identity. Thus, the first argument that I make is that these metaphors of vision are indeed discursive strategies employed by Turkish foreign policy elite to frame and to justify various foreign policy goals. Since metaphors are more powerful signifiers than simple words modifying the discourse, and since these metaphors of vision contain the claim to accomplish several things at a time, their capability to help shape reality is more powerful.

The literature about the use of metaphors in politics is vast. Those that have researched this topic have argued that metaphors can create "new contexts" and "establish new relationships,"11 and thus impact how reality (along with knowledge) is created, understood, disseminated ${ }^{12}$ and also reinforced..$^{13}$ Moreover, metaphors not only shape reality, but also help it to "gain authority." ${ }^{4}$ This, in turn, aids policy makers in legitimising and justifying their policies, not only to themselves, but also to the masses. ${ }^{15}$ In other words, metaphor is more than a simple linguistic, conceptual construct; it is a cognitive and a discursive tool, which, step by step, can help the reasoning of the rulers and the ruled. ${ }^{16}$ Aside from the arrows of reasoning released in the minds, some scholars even argue that despite the hard-to-prove causal link, metaphors might even be considered as the first steps taken towards an action, including a policy maker's choices as well as his/her goals. ${ }^{17}$ Finally, metaphors are extremely important sources of ambiguity, which give a good deal of leeway for politicians to manoeuvre while thinking, speaking and making policies,${ }^{18}$ deflecting responsibility as a result. ${ }^{19}$ Overall, from an elite perspective, metaphors are extremely useful constructs that create a favourable context to pursue their policies, ${ }^{20}$ serving the policy goals of these elites. When policy makers say that "country X is a bridge," or "is positioned at a crossroads," they are not simply using some vivid language to make their statement. Rather they are combining a discursive practice, with a geopolitical imagination/representation, and also, with an international function and identity they are aspiring to play and become. That way, metaphors of vision are more powerful than a mere geopolitical imagination or a representation or a mere use of metaphor. 
Metaphors of visions are discursive strategies that combine territorial, functional and ideational self-perception with a linguistic practice that furthers and deepens the "exceptionalist lore" that a state needs to survive and thrive. ${ }^{21}$

The second argument that I put forward is that although after the end of the Cold War, Turkish foreign policy elite used the very same "bridge" metaphor, because it justified and framed different foreign policy choices in different contexts, the meaning that was associated with the metaphor also changed. Consequently, since the meaning associated with the metaphor was also transformed, Turkey's liminality was also reinforced in different realms. As will be argued below, when Turkish foreign policy elite used the "bridge" metaphor throughout the 1990s, they portrayed Turkey as a country having a hybrid international identity. That is, Turkey was portrayed as a country with each foot in a different continent, Europe and Asia that is, and belonging equally to two different civilisations, Western and Eastern at the same time, yet mostly carrying Western values, i.e., more democratic compared to the surrounding countries, a market economy, secular, etc. While this hybridity helped Turkey to make the case for Turkey's liminal identity, or to quote Rumelili, Turkey was a "prime example of a liminal state,"22 it highlighted Turkey's commonality with Europe rather than its differences.

However, after the 9/11 attacks and the accession of the "reformed Islamist" AKP (Justice and Development Party) to power, this portrayal of a hybrid Turkey got a new twist. Though some of these hybrid features of Turkey such as being in the two continents, etc., were kept, religion was introduced into the discourse. This introduction happened when the AKP launched the United Nations (UN)-led "Alliance of Civilizations" initiative with Spain and made the claim that Turkey, in addition to "bridging" continents and Eastern and Western civilisations, could also "bridge" "West" and "Islam." This was a novelty because, bringing Islam, a feature that is not inherent to Europe, into discourse, while keeping Turkey's liminality on some grounds intact, it also introduced some level of marginality to Turkey's international identity, making Turkey liminal-marginal. No matter how Turkish officials insisted on using the metaphor bridge in the sense of a mediator or an arbiter, Turkey, in a sense, ended up becoming a possible spokesperson for Islam. That way, while Turkish foreign policy elite continued to use the same "bridge," because they used it in a different context, the meaning of the "bridge" metaphor changed from one of mediator/stabiliser/ facilitator to a spokesperson. In sum, this article is neither about the making of Turkish geographical "exceptionalism," nor about making the case for a causal link between metaphors, policy choice and policy outcome. Rather, it is about the deconstruction of this geographical "exceptionalism" puzzle that is often used by Turkish foreign policy makers utilising metaphors as discursive strategies.

In order to analyse this puzzle, I tracked down speeches that were delivered at various fora by the top-level Turkish officials involved in the 
making of Turkish foreign policy from the 1990s until today. Though the making of Turkish foreign policy rests mostly with the Ministry of Foreign Affairs, because of their extensive involvement, I have included the speeches of prime ministers or presidents. Additionally, because the governments changed very frequently in Turkey in the 1990s, I limited my analysis to the speeches of prime ministers and ministers of foreign affairs who stayed in power more than a year. Some of these speeches, especially for the speeches of Turgut Özal, Süleyman Demirel, Tansu Çiller, İsmail Cem, Bülent Ecevit, and Abdullah Gül (as the minister of foreign affairs) I benefited from a collection of speeches that had been published. For Recep Tayyip Erdoğan, Ali Babacan and Abdullah Gül (as the president), the Internet, websites of the appropriate government branch and newspapers were the primary sources. When I used newspapers or the Internet sources, I made sure that these were exact quotes of the foreign policy elite. That is, I paid particular attention to the use of metaphors of vision denoting Turkey's "uniqueness" or "exceptionalism." I then put these references into a timeline taking a note of the way the metaphors were used, of the context in which they were used and also of the audience that these speeches containing the "bridge" metaphor were delivered to. Here, I should also note that some Turkish officials more frequently used the "bridge" metaphor than others. In the texts that I analysed some Turkish officials like Necmettin Erbakan, Bülent Ecevit and Ahmet Necdet Sezer never or rarely use the "bridge" metaphor. Overall, Turkish metaphors of vision contribute to the field by showing that metaphors are dynamic, rather than static constructs, which help policy elites justify and frame their policy choices discursively.

\section{LOCATING TURKEY IN THE POST-COLD WAR ERA: HOW METAPHOR AND LOCATION STAYS THE SAME WHILE MEANING CHANGES}

Turkey's "important," "unique," "exceptional," or "difficult" geography or "Turkey's geopolitics" are the most frequently mentioned characteristics of the country's politics. Bilgin argues that the idea of geopolitics (or jeopolitik, in Turkish), first entered into the Turkish lexicon through the Turkish Armed Forces after World War II. After it emerged within the military, the word geopolitics and thus the issue of underscoring Turkey's location took on a life of its own among civilian elites. The geopolitics discourse, then, was used to justify Turkey's external and internal security policies. ${ }^{23}$ However, tracing the evolution of jeopolitik from official documents to school textbooks, is not the only way to analyse the reconstructions of the geography that Turkey occupies. Analysing the metaphors of vision that Turkish foreign policy elite employed in the post-Cold War period can tell us about geopolitical constructions, and about much more, as well. 
There are two reasons why this analysis is limited to Turkey's metaphors of vision produced in the post-Cold War period. The first reason is to make this project more manageable in terms of scope. Even this period is enough to make the case that metaphors are dynamic constructs helping elites justify their foreign policy options. This limitation, naturally, does not mean that Turkish foreign policy elite did not use metaphors of visions before the end of the Cold War. As mentioned earlier, throughout the twentieth century different metaphors were employed to describe Turkey, or its uniqueness. ${ }^{24}$ The second reason is that the post-Cold War period was like a social science lab for Turkey (and many others), in a sense, enabling the analysis of how policy makers discursively react to changing structural parameters at the international level. It was a period where Turkey's location, international function and identity had started to be debated as the Cold War was coming to an end. In 1989, for example, Turkey's application for European Community (EC) membership was rejected, dashing Turkish policy makers' hopes to officially become part of "Europe." Two years later, when the Soviet Union dissolved, Turkey's function and identity had to be resized and redefined. During the Cold War, capitalising on its geographical "exceptionalism" by presenting itself as a "bastion" or a "bulwark," on the southern flank of NATO, Turkey had to play the protector role in the first line of defence against communism. However, since the days of communism were over, security was no longer the prime issue that Turkey's foreign policy elite could use to make their case for an important role. ${ }^{25}$ They had to find something else to highlight the country's continued importance in world politics.

Turkish foreign policy discourse during these years is reflective of the foreign policy makers' struggle to redefine Turkey's role and identity in the new global order. Though in the immediate aftermath of the Cold War, rhetorically, Turkish foreign policy elite kept affirming and reaffirming how "unique" "special" or "important" Turkey's geography still was, ${ }^{26}$ they nevertheless had to put this rhetoric into practice as well. For example, after the first Gulf War, Turkey allowed Operation Provide Comfort/ Operation Northern Watch, which kept Kurds in Northern Iraq away from the reach of Saddam Hussein, to operate from Turkey. ${ }^{27}$ Moreover, Turkey pursued an active policy of drawing the international attention to the ethnic war in Bosnia-Herzegovina. ${ }^{28}$ It was, however, Turkey's ties to the East, especially with the Turkic Republics of the former Soviet Union, which became the leverage that Turkish officials were looking for at the international level. And it was within this context that Turkish officials mostly, but not exclusively, started to employ metaphors of vision. Once again, just like in the days of the Cold War, Turkish foreign policy elite chose to capitalise on Turkey's geographical "exceptionalism."

Interestingly, initially, Turkish officials preferred to describe these ties with the Turkic Republics in neutral terms. ${ }^{29}$ Then, for a while, Turkey was portrayed as a "gate" to Eurasia, or a "gate" between East and West. ${ }^{30}$ After 
using the "gate" and the "bridge" metaphor simultaneously in late 1994 and early $1995,{ }^{31}$ the Turkish foreign policy elite settled on the "bridge" metaphor. Two trends of meaning can be observed in the way these metaphors are used: Turkey portrayed as "bridging continents," and Turkey portrayed as "bridging civilisations."

Turkey Bridging Continents: The Midwife of "Eurasia" and a ModelStabiliser-Facilitator

As the Cold War was coming to an end, Turkish officials claimed that Turkey could be a "bridge" between "Europe and the Middle East." ${ }^{32}$ After the end of the Cold War, in addition to Europe and the Middle East, suddenly other continents worth "bridging" appeared on the maps of Turkish officials: Asia, Central Asia, West Asia, but most importantly, Eurasia. Turkish officials perceived and portrayed Turkey as located in the "heart" 33 of Eurasia, and as helping to reunite two continents that had been separated for years: Europe and Asia. For Hikmet Çetin, Minister of Foreign Affairs between 1991 and 1994, Turkey was located "at a crossroads, meeting point of a key region, Atlantic, Europe, Eurasia region, that with the help of scientific, technological and economic potential would turn into a locomotive of global peace and welfare." 34 Some others, like İsmail Cem, the Minister of Foreign Affairs between 1997 and 2002, and one of the most important advocates of the "Eurasia" idea in Turkey, went as far as to say that "Turkey was both European and an Asian." 35 The mindset of the Turkish foreign policy elite in the early post-Cold War years was that Turkey was an "island" or a "bastion" of stability in the midst of a troubled region. 36 To quote Cetin, Turkey's geography dictated Turkey's responsibility to create a "peace belt" using political and economic cooperation as a tool. ${ }^{37}$

In 1995, for example, then Prime Minister, Tansu Çiller, who would be the minister of foreign affairs in a year, while commenting on the possible delay in Turkey's entry into the Customs Union with the European Union, would play into the hands of her rival Islamist party in Turkey, and was quoted by Time magazine as such:

And is not just Turkey that is concerned there: there are also millions of Turkic speaking people of Central Asia who are looking at two models: ours or the Iranians. I see my tasks as changing the history because Turkey can become a bridge for peace between the two areas. If it does not, the two regions will be divided in confrontation with each other. We can be the link. We are democratic, we are secular and our economy is the first open, sophisticated economy in the area. ${ }^{38}$

Similarly, on one rare early occasion that Süleyman Demirel used the bridge metaphor, he said: 
Turkey, with its 60 million population, money and other possibilities, is a bridge to West Asia, to the Middle East. It is a model for Muslim countries. . . . Here's the model: an independent, democratic, secular country, employing a free market economy. Turkey is the only model. ${ }^{39}$

When, for example, Demirel is asked to comment on Turkey's ties with the EU, he summarises in one paragraph the evolution of the Turkish mindset, which declared that Turkey was a "bridge" to Eurasia.

After the collapse of the Soviet Union, Turkey, once a castle of defense [sic] has turned into bridge. That is, Eurasia has come into being, [Turkey] has become a bridge between Europe and Eurasia. In a sense, it [Turkey] has become a stepping stone, it has not lost its strategic importance, yet, in addition to this has improved its eco-strategic importance. ${ }^{40}$

Excerpts from the Turkish elites show that using these metaphors of vision helped them to kill three birds with one stone. First, still keeping (for the most part) the "bridge" to the Middle East, these metaphors helped to justify their role in newly "discovered" Eurasia as an economic/governance mediator/model/facilitator. ${ }^{41}$ Turkey, to Turkish officials, was the best democratic, secular - yet Muslim - country in the region for the newly independent Turkic republics (and to some extent, for the Middle Eastern countries) to use as a model. Second, Turkey was performing an international public service, so to speak, for the good of everyone involved. By portraying Saudi Arabia and Iran as the bogeymen, Turkey was the bulwark against the danger of religious extremism that these countries could spread. Moreover, Turkey was presented as an actor that could possibly help these resource-rich countries of the former Soviet Union to open up to world economy. Third, consequently, because Turkey was helping these newly independent states to stand on their own feet, it was midwifing the birth of a new continent: Eurasia. But more importantly, Turkish officials expressed their interest to become a mediator-stabiliser-facilitator in the region by bringing Western values, democracy, market economy and secularism to the region. Though proposing to be a "bridge" in the sense of a mediatorstabiliser-facilitator in a newly emerging region still maintained Turkey's liminal identity, Turkish officials could illustrate Turkey's continued usefulness and importance to the United States and the EU practically and discursively.

Turkey Bridging Civilisations: From Bridging "East and West" to Bridging "West and Islam" and Becoming the "Spokesperson" for Islam?

While Turkey "bridging continents" was the discourse dominating Turkish foreign policy elites' perceptions in the 1990s, Turkey "bridging civilisations" 
replaced this in the subsequent years, becoming the prevailing discourse in the 2000s. Using the bridge metaphor this time to connect civilisations, Turkey was initially portrayed more as an arbiter, or a mediator that could connect with and create peace among civilisations, than as a possible spokesperson for Islam.

Two points are important in this specific discourse. First, although "bridging civilisations" has become the leading discourse in Turkey in the 2000s, one can see the traces of Turkish elites perceiving Turkey as "bridging civilisations," as early as late 1993, long before it dominates the discourse. Speaking to the members of the European Media Union, Ciller described Turkey as:

the meeting point of continents and civilizations. ... We are the heir to the Roman, Greek, Ottoman and many other cultures. All these past civilizations have enriched our culture and understanding. The bridge at the Istanbul Strait countries [sic] not only physically connects Asia and Europe, but also in terms of values. ${ }^{42}$

As Ciller's statement coincides with the publication of Samuel Huntington's famous article "The Clash of Civilizations" in Foreign Affairs, in the summer of 1993, her timing is neither an accident, nor is she alone in portraying Turkey as a "bridge between civilizations." İsmail Cem also highlighted Turkey's "multicivilizational past," (or "geography of civilizations," 43 as he later coins) as early as 1995, first as the Minister of Culture ${ }^{44}$ and then as the Minister of Foreign Affairs. Cem believed that "history is the decisive factor in defining Turkey's past and her present." 45 After listing Turkey's "five main assets" of Turkey, which, according to Cem, were history, culture, "thriving" economy, stability and the "Turkish Model," 46 Cem, in September 1997 at the UN General Assembly, argued that one basis of Turkish foreign policy should be "Turkey's historical geography." ${ }^{47}$ For Cem, Turkey,

located at the crossroads of three continents and several regions, including the Balkans, the Middle East, the Caucasus and Central Asia, has an effective role in the maintenance of peace, security and stability in its wider region. We have lived together with peoples who actually constitute 26 contemporary independent States [sic]. Today, the historical and cultural attributes of this vast geography, more than ever, find their expression in Turkey's foreign policy. .. ${ }^{48}$ At the dawn of a new millennium, we are confident that Turkey will have a leadership role in its wider region. It will continue to be the bridge, the communicator and the peacemaker. ${ }^{49}$

Even in the late 1990s, Turkish officials had started to play the civilisation card against a reluctant EU. In November 1997, for example (just before the Luxembourg Summit that did not grant Turkey EU candidate status), 
Turkey's supposed ability to "bridge civilisations" started to become a tool to justify Turkey's EU membership. Cem, for example, said that

the EU is now deciding on its enlargement process. One important decision is what role to offer Turkey, which provides Western Europe's main historical, cultural and economic links to Eastern horizons. The choice that the EU makes will either provide the EU with a crucial bridge of conciliation with civilizations of other characteristics, or will be discriminatory and have no effect, or even negative effects on the persisting dichotomies. $^{50}$

In 1998, at the opening ceremony of the Turkish Parliament, Demirel made a similar reference. "Turkey," he said, "with its position bridging North and South and East and West, assumes a major role in contributing to the harmonization of cultures and civilizations." 51 Though the statement did not directly address the EU, nevertheless, it was clearly meant to send a message to the EU that was dragging its feet regarding Turkey's membership.

Yet this early understanding of "civilisations" that highlighted common points with the West, both in terms of roots and values, was replaced with an understanding of civilisation that did not highlight commonalities, but rather a difference. That is, in the early 2000s, Islam entered into the Turkey's "bridging" discourse, eventually becoming one of the contexts in which the "bridge" metaphor was used. In addition to Huntington's "Clash of Civilization" thesis, several other issues prepared the ground for this change. First, towards the end of the 1990s, it became clear that Turkey "bridging continents," i.e., being a model/stabiliser/facilitator to/for the countries to its East, especially for the Turkic republics did not look like something that was viable. Throughout the 1990s (and even today), Turkey was embroiled in an armed struggle with Kurdish separatists, meaning that the country that was offering stability to others was not itself that stable. What is more, Turkey experienced several major economic crises during these years, combining economic instability with the political one. It was soon clear that Turkey neither looked like a model/stabiliser/facilitator nor were these countries willing to see Turkey as such. This situation ended the credibility of a discourse in which Turkey was portrayed as a "bridge" between "continents," taking Western values to the East. This of course, did not mean that Turkish officials completely stopped using the Turkey "bridging continents" discourse. That discourse also continued, but faded into the background because of the emergence of the discourse based on Turkey's supposed ability to "bridge civilisations."

In addition to the limited opportunity that the "bridging continents" discourse had, the 9/11 attacks gave the opportunity to Turkish foreign policy elite to declare Turkey a "bridge" that connected "civilisations." The fact that perpetrators and the masterminds of the 9/11 attacks were Muslims 
and that in the aftermath American president George W. Bush declared America to be on a "crusade" against terrorism indicated that Samuel Huntington's "Clash of Civilizations" thesis was finding supporters within the American foreign policy circles and among their like-minded allies. Turkish foreign policy elite were simply reacting to this discourse. More important than the increased support for the Clash of Civilizations thesis, the attacks of 9/11 firmly introduced a discourse centred on "civilisations," producing, reproducing and reinforcing the image of a Manichean world based on two religions - Islam and Christianity.

In February 2002, for example, a few months after the 9/11 attacks, Turkish officials got the chance to put their rhetoric regarding civilisations into action by hosting a joint forum called "The Meeting of Civilizations" with the Islamic Conference Organization (ICO) and EU member and candidate countries in Istanbul. İsmail Cem in his speech said that "Turkey was hosting this forum with a special duty and a mission. We have ties to both ICO and the EU. We are at the same time both European and Asian country. We are the representative of culture that has roots both in the East and the West." ${ }^{52}$ At that meeting, even Bülent Ecevit, Prime Minister at the time, and who rarely used metaphors of vision in his speeches, said, "We are in a position to bridge Europe and Asia, and East and West." 53 This version of the "civilisations" discourse developed in the late 1990s and around 2001, was quite different from what it would become in a couple of years' time. It was more cultural, less religious and it was willing to portray Turkey as the heir of empires of pre-Ottoman Anatolia, emphasising a degree of commonality with the West, especially with Europe.

The religious twist to the "Turkey bridging civilisations" discourse, however, came to the forefront after the Justice and Development Party (AKP) came to power in November 2002. The AKP, which some observers call a "reformed Islamist party," was established in 2001, by a splinter group from the last of the series of parties that successively represented the religious conservative National View movement. Although the AKP presented itself as "conservative democrats" and a centre party, it was during their time that the religious twist was added to the Turkey "bridging civilisations" discourse. This religious twist came with the launching of the "Alliance of Civilizations" initiative in 2004. Recep Tayyip Erdoğan, Turkish Prime Minister and the head of the AKP, and the Spanish Prime Minister, Jose Luis Rodriguez Zapatero who led the initiative officially described the "Alliance of Civilizations" as an effort "to contribute to the creation of unity, cooperation and harmonization by attaching priority to common universal values between cultures." ${ }^{54}$ More interesting than the initiative's goal were Erdoğan's remarks about what Turkey was bridging this time: the West and Islam.

Some circles are trying to interpret 11 September as the preliminary signal of clash among civilizations and religions. It is necessary to stress 
that clash among religions is not inevitable. The real clash is between those who are Muslim, Christian or Jewish who adopt universal values and those who believe in the opposite. .. Within this context EU membership of Turkey will be a significant contribution to establishment of a bridge between the West and Islam [sic] world. Together with Turkey's EU membership, criticisms and racism accusations like 'EU is a Christian Union' will end. ${ }^{55}$

Replacing "East and West," or using it along with "West and Islam," or with "Islam and Christianity," makes a big difference in the way Turkey is portrayed, perceived and presented. Here it should be noted that while PM Erdoğan preferred to portray Turkey as "bridging West and Islam," other members of the AKP, such as (the former Minister of Foreign Affairs and the current President) Abdullah Gül, just like his predecessors portrayed Turkey "at the intersection of different regions," 56 or said that Turkey "constitute[d] a natural bridge between Europe or Asia." 57 However, as Kösebalaban argues, adding a religious flavour to the civilisations discourse is an immense change of Turkish attitude towards Europe. Because until the AKP took over Turkey's European vocation, the point of Turkey's membership to EU was that Turkey would be integrated into some other "civilisation." Now that Turkey was assuming this role between Islam and Christianity, the AKP government was asking Europe to accept Islam, another civilisation, into Europe. ${ }^{58}$ Taking the vague concept of "universal values" as a base, Turkey was, in a sense, volunteering for the task of presenting Islam, a religion, and one that is not inherent to West, rather than the East, to the West. This meant the introduction of a less secular and more religious sense about Turkey's location, role and identity, and highlighted Turkey's Islamic credentials, rather than its commonality with Europe in other realms. With this change the "bridge" metaphor acquired not only a more religious flavour, but also a meaning that presented Turkey as a possible spokesperson for Islam.

Such a shift was not without reason. As his predecessors did, Erdoğan was trying to make a case for Turkey's EU membership by highlighting Turkey's location, function, and identity albeit in a less religiously neutral way. This especially was to deflect the criticism coming from the EU regarding the slowdown of the EU reforms. ${ }^{59}$ Being a bridge between "Islam and the West," was thought of as a handy rhetorical tool to justify Turkey's stance not only towards the EU, but also towards the Middle East.

Erdoğan's speech delivered at the American Enterprise Institute, in Washington, DC, in 2004, is a good example of the amalgamation of the older secular rhetoric with a more religious one, and of presenting Turkey to the Middle East as brothers in religion. In this speech, Erdoğan, still maintained the argument that Turkey could be a "model" to the Muslim world "in an inspirational way," 60 and stated that "the secular and democratic structure of Turkey, a country which acts as a bridge between the East and the West, 
Islam and Christianity, as well as Europe and Asia, lives in harmony with traditions footed in Islamic culture." 61 He heralded Turkey's "new" role in the Middle East by saying that

\begin{abstract}
with its own stable and successful model of development, its place in the Western world, and its rich historical legacy and identity, Turkey will be a symbol of harmony of cultures and civilizations in the $21^{\text {st }}$ century. Turkey will help achieve this not merely through its economic and military power, but its ability to make contributions to the universally accepted values and facilitate their dissemination and interaction among various parts of the world. In this sense, Turkey in its region and especially in the Middle East will be a guide in overcoming instability, a driving force for economic development, and a reliable partner in ensuring security. ${ }^{62}$
\end{abstract}

Indeed, during the AKP's first term, Turkey took several steps towards the Middle East that were somewhat controversial, but reflected the AKP government's desire to make Turkey a "bridge" to the Middle East, and more importantly to the Islamic world. Turkey was presented in such a way that, having a predominantly Muslim population enabled the country to understand the dynamics of the Middle East. When, for example, the United States introduced the Greater Middle East Project, the members of the AKP government very explicitly stated that they would "move together with the United States for the Greater Middle East Project, in order to bring freedom and democracy to Islamic countries." 63 Turkey frequently expressed its interest in mediating the conflict between Israel and Palestine, something which did not find many supporters in the Middle East. ${ }^{64}$ Partially as a result of this, and partially because of the AKP's desire to act on the problem, Khaled Mashaal, the political leader of Hamas, was invited to Ankara by the AKP in February 2006, which created a mini diplomatic crisis between Turkey and Israel. ${ }^{65}$ Finally, the upper echelons of the AKP offered to play the mediator role yet again between "the West and Islam," during the infamous Danish Cartoon Crisis of February-March 2006. ${ }^{66}$ In the latest series of mediator roles that Turkey wanted to play, talks between Israel and Syria were hosted in Istanbul, in July 2008. ${ }^{67}$ In sum, the "bridge" metaphor helped the AKP government lead Turkey to achieve several goals. First, like before, the "bridging" discourse made the case for the continued utility of Turkey to Europe. Second it justified Turkey's active policy in the Middle East. The discourse that accompanied all these was one that seemingly presented Turkey as a mediator between Islam and Christianity, but in reality, was attempting to speak for Muslim countries. The introduction of Islam into the civilisations discourse, not only altered the meaning of the bridge metaphor, but also disturbed the liminal category that Turkey was placed in. As Islam is innate to neither to Europe nor to the EU, Turkey 
moved from being liminal to being liminal-marginal, making itself even harder to categorise.

\section{CONCLUSION}

No foreign policy activity can develop in a vacuum. It has to be supported by a discourse. The discourse that a policy choice is embedded in not only justifies the choice, but helps foreign policy makers frame it for themselves as well as for their domestic and international audiences. What is more important than the discourse in which the foreign policy choice is implanted, are the discursive strategies used to formulate this discourse. That is, saying that the location of Turkey (or some other country) is "important" is different from saying that Turkey is a "bridge." In the Turkish case, a metaphor that seemingly highlights only a country's location means much more. It gives us clues about the role a state wants to play, thus contributing to the international self of that country. Overall, the choice of metaphor tells us much about the visions - geopolitical, functional and ideational - of a country.

This paper also shows that, although metaphors employed stayed the same, the meaning of the metaphor changed. Tracing the way Turkish officials used the "bridge" metaphor since the end of the Cold War, this paper illustrated that initially, the "bridge" metaphor stemming from the "exceptional" geography, in the early 1990s became a discursive strategy supporting the formulation of Turkey's foreign policy to its East, especially with the Turkic Republics of the former Soviet Union. Turkey during those years was predominantly portrayed as "bridging continents," meaning that it was willing to become a model/facilitator/stabiliser for the newly emerging Eurasia. After the 9/11 attacks, with the advance of the AKP to power, on the other hand, the "bridge" metaphor combined with the civilisation discourse that had already been in circulation, gained more strength carrying a more religious, less secular meaning, helping portray Turkey as a spokesperson of Islam. This was thought to be a strategy justifying Turkey's continued usefulness for Europe as well as its policy in the Middle East. However, regardless of the strategy, justifying and framing a policy does not guarantee a successful outcome.

The use of "bridge" metaphor in the Turkish context contains an inherent paradox. First, the use of bridge metaphor reinforces Turkey's not just any "othering" but its "liminality." And, since the "bridge" metaphor is a metaphor of vision, this othering not only happens in terms of geography, but in terms of values, and recently religion, as well. Of course, Turkish officials are not alone in producing and reproducing of Turkey's liminal position. Many others, such as Americans, ${ }^{68}$ Germans, ${ }^{69}$ and EU Commissioners ${ }^{70}$ have described Turkey as a "bridge." Even those 
who did not agree with the "bridge" metaphor, such as former German Chancellor Helmut Schmidt ${ }^{71}$ who claimed that Turkey was not a bridge, contributed to the discourse, and reinforced Turkey's liminality simply by putting Turkey's "bridgehood" one more time into circulation - albeit in a negative fashion.

Though liminality is sometimes branded as a bad thing, certain countries may want to create a label of liminality as Turkey does. The "bridge" metaphor gave this exact discursive support that Turkish foreign policy makers in the post-Cold War international order needed to prove their usefulness to Europe and to advance their particular foreign policy agendas for Eurasia and the Middle East. The viability of this discursive strategy, however, is very much open to question, especially when there are many other issues on Turkey's to-do list in order to become an EU member. As interesting as the adoption of liminality may be, this discourse started a cycle that looks enigmatic, yet is dangerous because it discursively and practically reinforces Turkey's liminal, no matter what spin Turkey's foreign policy makers put on it.

\section{ACKNOWLEDGEMENTS}

Earlier versions of this paper were presented at the International Studies Association (ISA) Annual Meeting in San Francisco, CA, USA, 26-29 March 2008 and European Consortium for Political Research (ECPR) Joint Sessions - Workshop \#8, 10-16 April 2008, in Rennes, France. The author thanks the workshop participants, the three anonymous reviewers of Geopolitics, Pınar Bilgin and Berrak Burçak for their helpful suggestions and Ceren Eren, Şeyma Dağıstan and Nurşah Alpay for their research assistance. The usual disclaimers apply.

\section{NOTES}

1. See M. Aydin and S. Tezel-Aydın, Turkish Foreign Policy Bibliography: Sources in English, French and German, 1919-2001 (Ankara: Center for Strategic Research 2002) for a list of titles in English that contain the words "East" and "West" regarding Turkey's foreign policy and that obviously, is not inclusive. A lot more can be added to this list with other sources in other languages including Turkish. See for example, H. E. Adivar, Conflict of East and West in Turkey (Lahore, Pakistan: S. M. Ashraf 1935); H. İnalc1k, 'Turkey Between Europe and the Middle East', Perceptions 3/1 (March-May 1998) pp. 5-18; F. Tachau, 'Turkish Foreign Policy: Between East and West', Middle East Review 17/3 (Spring 1985) pp. 21-26; L. Ruhl, 'Turkey, Between Europe and the East', Europa-Archiv 47/11 (1992) pp. 295-302; G. Güzeldere and S. Irzik (eds.), Relocating the Fault Lines: Turkey Beyond East/West Divide (Durham, NC: Duke University Press 2003); İ. Sosyal (ed.), Between East and West: Studies on Turkish Foreign Policy (Istanbul: Isis Press 2001); L. Rittenberg (ed.), The Political Economy of Turkey in the Post-Soviet Era: Going West Looking East (Westport, CT: Praeger 1998); V. Mastny (ed.), Turkey Between East and West: New Challenges for A Rising Regional Power (Boulder, CO: Westview 1996). 
2. J. Noyon, 'Bridge Over Troubled Regions', Washington Quarterly 7/3 (1984) pp. 77-85; E. Kalaycıoğlu, Turkish Dynamics: Bridge Across Troubled Lands (New York: Palgrave 2005); N. Kandemir, 'Turkey: Secure Bridge Over Troubled Waters', Mediterranean Quarterly 8/4 (Fall 1997) pp. 1-12.

3. A. Saikal and C. Kersetz, Turkey: A Bridge Between East and West (Canberra: Centre for Middle Eastern and Central Asian Studies 1996); P. Holmes, Turkey: A Timeless Bridge (Istanbul: Shell Company 1988); F. A. Vali, Bridge Across the Bosphorus: A Foreign Policy of Turkey (London and Baltimore: The Johns Hopkins Press 1971); I. O. Lesser, Bridge or Barrier? Turkey and the West After the Cold War (Santa Monica, CA: Rand Corporation 1992).

4. To cite a few examples, Slovenia is referred as a "bridge"; the metaphor that applies to the Caribbean and Afghanistan is "crossroads"; the European Union, on the other hand, was accused of becoming a "fortress". See, 'Diplomats Discuss Slovenia's Role as a Bridge to SE Europe', available at <http://www.ukom.gov.si/eng/slovenia/publications/slovenia-news/1796/1809/>; A. G. Ramos and A. I. Rivera (eds.), Islands at the Crossroads: Politics in the Non-Independent Caribbean (Boulder, CO: Lynne Reinner 2001); K. Masatoshi, Afghanistan: Crossroads of the Ages (Tokyo and Palo Alto: Kodansha International 1969).

5. P. Tank, 'Dressing for the Occasion: Reconstructing Turkey's Identity', Southeast European and Black Sea Studies 6/4 (Dec. 2006) pp. 463-478.

6. G. Dijkink, National Identity and Geopolitical Visions: Maps of Pride and Pain (London and New York: Routledge 1996).

7. Dijkink (note 6) pp. 5-14.

8. B. Rumelili, 'Liminality and Perpetuation of Conflicts: Turkish-Greek Relations in the Context of Community Building by the EU', European Journal of International Relations 9/2 (2003) pp. 213-248; R. A. Higgott and Kim R. Nossal, 'The International Politics of Liminality: Relocating Australia in the Asia-Pacific', Australian Journal of Political Science 32/2 (1997) pp. 169-186; and most importantly, Samuel Huntington referred to Turkey as a 'torn' country. S. P. Huntington, 'The Clash of Civilizations', Foreign Affairs $72 / 3$ (1993) p. 43.

9. From medieval times defining what and whereabouts of first the Ottomans and then the Turks, as the "other," "marginal," "liminal," or as the "ambiguous" partner, European powers, individually and collectively have defined themselves and also Turkey. Theoretical and empirical literature about Europe's and the EU's individual and collective "othering" practices is vast. To cite a few: Rumelili (note 8); Iver B. Neumann, Uses of the Other: "The East" in European Identity Formation (Minneapolis: University of Minnesota Press, 1999) esp. ch. 2; M. E. Yapp, 'Europe in the Turkish Mirror', Past and Present 137/1 (Nov. 1992) pp. 134-155; I. B. Neumann, 'European Identity, EU Expansion and Integration/Exclusion Nexus', Alternatives 23/3 (July-Sep. 1998) pp. 397-417; I. B. Neumann, 'Self and Other in International Relations', European Journal of International Relations 2/2 (1996) pp. 139-174; T. Diez, 'Europe's Others and the Return of Geopolitics', Cambridge Review of International Affairs 17/2 (2004) pp. 319-335; A. Cirakman, From the "Terror of the World" to the "Sick Man of Europe: European Images of Ottoman Empire and Society from the Sixteenth Century to the Nineteenth (New York: Peter Lang 2002); C. Keyder, 'The Dilemma of Cultural Identity on the Margin of Europe', Review 16/1 (Winter 1993) pp. 19-33; M. Müftüler-Baç, 'Through the Looking Glass: Turkey in Europe', Turkish Studies 1/1 (Spring 2000) p. 22.

10. See note 1 and note 3 .

11. F. A. Beer and C. De Landsheer, 'Metaphors, Politics and World Politics', in F. A. Beer and C. De Landsheer (eds.), Metaphorical World Politics (East Lansing: Michigan State University Press 2004) p. 6.

12. Beer and De Landsheer (note 11) Foreword.

13. P. McGreevy, 'Reading Texts of Niagara Falls: The Metaphor of Death', in T. J. Barnes and J. S. Duncan (eds.), Writing Worlds: Discourse, Text and Metaphor in the Representation of Landscape (London and New York: Routledge 1992) p. 50.

14. Barnes and Duncan (note 13) p. 9

15. P. Chilton and M. Ilyin, 'Metaphor in Political Discourse: The Case of the 'Common European House', Discourse and Society 4/1 (1993) p. 10.

16. G. Lakoff and M. Johnson, Metaphors We Live By (Chicago: The University of Chicago Press 1980) pp. 3-6; G. Lakoff, 'Metaphor and War: The Metaphor System Used to Justify War in the Gulf', Journal of Urban and Cultural Studies 2/1 (1991) pp. 59-72.

17. K. L. Shimko, 'Metaphors and Foreign Policy Decision Making', Political Psychology 15/4 (1994) p. 655.

18. Lakoff (note 16) p. 59. 
19. Chilton and Ilyin (note 15) pp. 7-31.

20. L. W. Hepple, 'Metaphor, Geopolitical Discourse and the Military in South America', in T.J. Barnes and J.S. Duncan (eds.), Writing Worlds: Discourse, Text, and Metaphor in the Representation of Landscape (London and New York: Routledge 1992) p. 136; Lakoff (note 16).

21. G. O’Tuathail and S. Dalby, 'Introduction: Rethinking Geopolitics: Towards a Critical Geopolitics', in G. O'Tuathail and S. Dalby (eds.,) Rethinking Geopolitics (London: Routledge 1998) p. 3.

22. Rumelili (note 8) p. 221.

23. P. Bilgin, 'Only Strong States Can Survive in Turkey's Geography: The Uses of 'Geopolitical Truths' in Turkey', Political Geography 26/ 7 (Sep. 2007) pp. 740-756.

24. B. Belge, 'Modern Turkey', International Affairs 18/6 (Nov.-Dec. 1939) p. 756. See also N. Erim, the prime minister in the 1970 s, describing Turkey being at the "intersection" of three continents at a UN meeting: 'Sayın Başbakanın Birleşmiş Milletler Asya-Afrika Gurubundaki Konuşmas1, New York, 20 Mart 1972', in Resmi Temaslar (n.p.: Doğuş Matbaacılık Ltd. 1972) p. 28.

25. P. Bilgin, 'A Return to 'Civilizational Geopolitics', in the Mediterranean? Changing Geopolitical Images of the EU and Turkey in the Post-Cold War Era', Geopolitics 9/2 (Summer 2004) pp. 280, 281.

26. See for example, T. Özal, Cumburbaşkan Turgut Özal'in III. İzmir İktisat Kongresindeki Konuşmaları (Ankara: Başbakanlık Basımevi 1992) p. 11; S. Demirel, 'Cumhurbaşkanı Sayın Süleyman Demirel'in TBMM'nin 19'uncu Dönem 3'üncü Yasama Yılının Açılışında Yaptıkları Konuşma' in C. Ergen (ed.), Cumburbaşkan Süleyman Demirel'in Söylev ve Demeçleri (n.p.: 2002) p. 2; T. Çiller, 'Başbakan Sayın Tansu Çiller'in Georgetown Üniversitesi'nde Fahri Doktora Töreninde Yaptığı Konuşma', in DYP Genel Başkan ve Başbakan Tansu Ciller'in Konuşmalar (19 Haziran-5 Kasım 1993) (Ankara: Başbakanlık Basımevi 1993) p. 269.

27. K. Kirişçi, 'Turkey and the Muslim Middle East', in A. Makovsky and Sabri Sayarı (eds.), Turkey's New World: Changing Dynamics in Turkish Foreign Policy (Washington, DC: The Washington Institute For Near East Policy 2000) pp. 53, 54.

28. S.. Kut, 'Turkish Policy Toward the Balkans', in A. Makovsky and S. Sayari (eds.) Turkey's New World: Changing Dynamics in Turkish Foreign Policy (Washington, DC: The Washington Institute for Near East Policy 2000) pp. 82, 83, 84.

29. See for example, Çiller, 'Başbakan Sayın Tansu Çiller'in Georgetown' (note 26) p. 270; S. Demirel, 'Başbakan Sayın Süleyman Demirel'in TBMM'de Hükümet Programını Sunuşu', in Başbakan Süleyman Demirel'in Konuşmalar, (20.11.1991-29.2.1992) (Ankara: Başbakanlık Basımevi 1992) p. 76.

30. S. Demirel, Başbakan Saym Süleyman Demirel'in 24.2.1992 Taribli Basın Toplantısı (Ankara: Başbakanlık Basımevi 1992) p. 33; S. Demirel, 'Başbakan Sayın Süleyman Demirel'in Le Figaro Muhabiri Claude Lorieux'ye Türkiye'nin Dış İlişkileri ve Güneydoğu Sorunu Hakkında Verdikleri Mülakat', in Başbakan Süleyman Demirel'in Konuşmalar (1.3.1992-31.5.1992) (Ankara: Başbakanlık Basın Merkezi, 1992) p. 189.

31. T. Çiller, 'Başbakan Sayın Tansu Çiller'in Saraybosna'ya Giderken Uçakta Basın Mensuplarıyla Yaptığ 1 Sohbet', in Başbakan Saym Tansu Ciller'in Konuşmaları (3 Temmuz- 31 Aralık 1995) (Ankara: Başbakanlık Basın Merkezi 1995) pp. 419, 420; Cumhurbaşkanı Sayın Süleyman Demirel'in 18 Ekim 1994 Tarihinde II. Türk Cumhuriyetleri Zirvesi'inin Açılışında Yaptıkları Konuşma in C. Ergen, ed., Cumburbaskani Süleyman Demirel'in Söylev ve Demeçleri (n.p: n.d, 2002) p. 670; Cumhurbaşkanı Sayın Süleyman Demirel'in Dış Politika Enstitüsü Tarafından Düzenlenen "21'inci Yüzyılın Eşiğinde Türk Dış Politikası" Konulu Konferansta Yaptıkları Konuşma," in C. Ergen (ed.), Cumburbaşkani Süleyman Demirel'in Söylev ve Demeçleri (n.p: n.d., 2002) p. 690.

32. T. Özal, '19 Şubat 1986 Günü Kraliyet Uluslararası İlişkiler Enstitüsünde (Chatham House) Başbakan Turgut Özal Tarafından Yapılan Konuşma', in Başbakan Turgut Özal'n İngiltere Ziyareti (17-20 Şubat) (Ankara: Başbakanlık Basın Yayın ve Enformasyon Genel Müdürlüğ̈̈, 1986) p. 39; T. Özal, Cumburbaşkanı Turgut Özal'm 3. İzmir İktisat Kongresindeki Konuşmaları, (4 Haziran 1992) (Ankara: Başbakanlık Yayınevi 1992) p. 25.

33. See for example, S. Demirel, Başbakan Saym Süleyman Demirel'in 14.4.1993 Taribli Basın Toplantısı (Ankara: Başbakanlık Basımevi 1993) p. 32; H. Çetin, 'Türkiye'nin Dı̣s Politika Öncelikleri', Yeni Türkiye No. 3 (1995) p. 56.

34. H. Çetin, Dışişleri Bakanı Hikmet Çetin Tarafindan Dışişleri Bakanlı̆̆ 1993 Mali Yılı Bütçe Tasarısını TBMM Genel Kurulunda Görüşülmesi Vesilesiyle Yapılacak Konuşma, (21 Aralık 1992) (Ankara: TC Dışişleri Bakanlı̆̆1 1992) p. 5.

35. I. Cem, Turkey in the $21^{\text {st }}$ Century: Speeches and Texts Presented at International Fora (1995-2000) (Lefkose: Rustem 2001) p. 13. 
36. T. Çiller, 'Başbakan Sayın Tansu Çiller'in İstanbul'da Aspen Enstitüsü Toplantısında Yaptı̆̆1 Konuşma' in Başbakan Sayin Tansu Ciller' in Konuşmalari (3 Temmuz-31 Aralik 1995) (Ankara: Başbakanlik Basin Merkezi 1995) pp. 182, 183; S. Demirel, '1995 Yllının Gelişmeleri ve 1996 Yllı Hedefleri, Cumhurbaskanı Süleyman Demirel (20 Ocak 1996- Ankara)', in C. Ergen (ed.), Cumburbaskani Süleyman Demirel' in Söylev ve Demeçleri (n.p: n.d., 2002) p. 297.

37. Çetin, 'Türkiye'nin' (note 33) p. 55.

38. Time, 20 Nov. 1995, quoted in Iver B. Neumann (note 9) pp. 61-62. Ciller makes similar remarks elsewhere. See T. Çiller, 'Başbakan Sayın Tansu Çiller'in Almanya Seyahati Öncesi Başbakanlık Konutu'nda Basına Yaptığı Açıklama (4 Aralık 1995)', in Başbakan Sayin Tansu Ciller' in Konuşmalari (3 Temmuz-31 Aralik 1995) (Ankara: Başbakanlik Basin Merkezi 1995) p. 429; T. Çiller, 'Başbakan Sayın Tansu Çiller'in Almanya Başbakanı Kohl İle Görüşmesinden Sonra Basına Yaptığ Açıklama' (5 Aralık 1995)', in Başbakan Sayin Tansu Ciller' in Konuşmalari (3 Temmuz-31 Aralik 1995) (Ankara: Başbakanlik Basin Merkezi 1995) p. 435; T. Çiller, 'Başbakan Sayın Tansu Çiller'in Bilkent Üniversitesi'nde Yaptığ1 Konuşma' (15 Aralık 1995), in Başbakan Sayin Tansu Ciller' in Konuşmalari (3 Temmuz-31 Aralik 1995) (Ankara: Başbakanlik Basin Merkezi 1995) p. 511.

39. S. Demirel, 'Başbakan Sayın Süleyman Demirel'in Alman ARD Radyosu Muhabiri Harald Weiss ve Efe Ajansı Muhabiri Juan Fernandes Elorriaga'ya Verdikleri Mülakat', in Başbakan Süleyman Demirel'in Konuşmalar (1.3.1992-31.5.1992) (Ankara: Başbakanlık Basın Merkezi 1992) p. 140.

40. S. Demirel, 'Cumhurbaşkanı Sayın Süleyman Demirel'in NTV Televizyonunda Yayınlanan Mülakat1, 21 April 1997,' in Cumburbaşkan Saym Süleyman Demirel'in Cesitli Televizyon Kanallarında Yaymlanan Mülakatları (Ankara: Başbakanlık Basımevi 1997) pp. 275, 276. Similarly, Bülent Ecevit believes that the emergence of Eurasia has helped Turkey to pursue a multifacted policy. See for example, B. Ecevit, 'Bölge-Merkezli Diş Politika', Yeni Türkiye 3 (1995) p. 69.

41. This is also noted by I. O. Lesser, 'Beyond 'Bridge Or Barrier': Turkey's Evolving Security Relations with the West', (note 27) p. 205.

42. T. Çiller, 'Başbakan Sayın Tansu Çiller'in Avrupa Medya Birliği'nin 5. Avrupa Televizyon ve Film Forum'unda Yaptığı Açış Konuşması (4 Kasım 1993)', in DYP Genel Baskani ve Basbakan Tansu Ciller' in Konusmalon (19 Haziran-5 Kasim 1993) (Ankara: Başbakanlik Basimevi 1993) p. 362;

43. İ. Cem, Türkiye, Avrupa, Asya, Vol. 1 (Istanbul: Bilgi Üniversitesi Yayınları 2004) p. 33.

44. Cem, Turkey in the $21^{\text {st }}$ Century (note 35) pp. 4, 5 .

45. Ibid., p. 1.

46. Ibid., p. 21

47. Ibid., p. 22.

48. Ibid., p. 22

49. Ibid., p. 24.

50. Ibid., p. 138.

51. S. Demirel, 'Cumhurbaşkanı Sayın Süleyman Demirel'in Türkiye Büyük Millet Meclisi'nin 20'inci Dönem 4'cü Yasama Yılının Açılışında Yaptıkları Konuşma' in C. Ergen, ed., Cumburbaskani Süleyman Demitel' in Söylev ve Demeçleri (n.p: n.d, 2002) p. 83.

52. I. Cem, 'IKÖ-AB Ortak Forumu: Cem'in Konusmasi', available at <http://www.belgenet.com/ arsiv/iko-ab-02.html>.

53. B. Ecevit, 'IKÖ-AB Ortak Forumu: Ecevit'in Açıklaması', available at <http:// www.belgenet.com/arsiv/iko-ab-04.html>.

54. 'Developments Related to The Civilizations Alliance Initiative', Newspot 53 (Nov.-Dec. 2005), available at <http://newspot.byegm.gov.tr/2005/nov-dec/ns8htm>.

55. 'PM Erdogan Speaks to Italian Il Mattion Newspaper-Erdogan: Turkey is a Bridge Between Islam and Europe', Anatolia News Agency quoted by BBC Monitoring International Reports, 1 Sep. 2005. Former Minister of Foreign Affairs Abdullah Gül has also been quoted using Islam and the West as the two sides of the bridge. See for example, G. Özalp, 'Türkiye Köprü Olabilir', Voa.com, 11 March 2006.

56. A. Gül, 'Dış Politikada Yeni Ufuklar', in A. Gül, Yeni Yüzyılda Türk Dış Politikasının Ufuklar (Ankara: T.C. Dışş̧leri Bakanlı̆̆ı Yayınları 2007) p. 84.

57. A. Gül, 'Walking the Tight Rope: Managing Turkey's Foreign Relations', in A. Gül, Yeni Yüzyılda Türk Dış Politikasının Ufukları (Ankara: T.C. Dişişleri Bakanlığı Yayınları 2007) p. 44. Similarly, Ali Babacan, who replaced Gül, as the Minister of Foreign Affairs, to a large degree, highlights Turkey's location, role and identity, just like his predecessors in the 1990s.

58. H. Kösebalaban, 'The Permanent "Other?" Turkey and the Question of European Identity', Mediterranean Quarterly 18/4 (2007) p. 96. 
59. 'European Union Tells Turkey to Deepen Reforms', VoaNews, 22 Nov. 2007.

60. R. T. Erdoğan, 'Conservative Democracy and the Globalization of Freedom', Speech Delivered at American Enterprise Institute, 29 Jan. 2004, available at <http://www.aei.org/include/ event_print.asp?eventID=735>.

61. Ibid.

62. Ibid.

63. N. İflazoğlu, 'Gül: BOP İçinde ABD Ile Birlikte Hareket Ediyoruz', Radikal 14 March 2006.

64. E. C. Gürkaynak, 'Turkey as a Third Party in Israeli-Palestinian Conflict: Assessment and Reflections', Perceptions 12/1 (Spring 2007) p. 101.

65. 'Israil'den Hamas Tepkisi', Milliyet, 10 Feb. 2006.

66. 'Türkiye Köprü Olabilir', VoaNews.com, 11 March 2006.

67. H. Keinon, 'Erdogan Gets Positive Domestic 'Bounce' From Mediating Israel-Syrian Talks', The Jerusalem Post, 31 July 2008.

68. R. Perle quoted in S. Bates and M. Walker, 'Turkey: Bridge Over Troubled Waters', The Guardian, 2 Dec. 1998; 'ABD Başkanı Clinton'un Türkiye Ziyareti 15-19 Kasım 1999', available at <http:// www.belgenet.com/arsiv/clintontbmm_05.html>; 'President Bush Meets with President Gul of Turkey', available at <http://www.whitehouse.gov/news/releases/2008/01/print/20080108-3html>; 'Dr. Rice Addresses War on Terror', available at <http://www.whitehouse.gov/news/releases/2004/08/print/ 20040819-5html>.

69. 'Steinmeier: Türkiye Köprü Oluşturabilir', Mynet Haber, 14 Jan. 2007, available at <http:// www.haber3.com/print.php?type=0\&id=196016>.

70. 'Rehn: 'Türkiye, Koprü Olabilir”, Maksimum.Com, 5 Aug. 2006.

71. 'Schmidt: Koprü Türkiye Değil', Radikal, 19 Nov. 2006. 